\title{
PEMBERIAN SANKSI TERADAP KETIDAKDISIPLINAN BELAJAR KELAS V SD NEGERI SE KECAMATAN TEMPEL
}

\author{
Muhammad Jurais \\ Program Pasca Sarjana Magister Studi Islam \\ Universitas Muhammadiyah Yogyakarta \\ E-mail: muhammadjurais11@gmail.com
}

\begin{abstract}
Abstrak
Penelitian ini bertujuan untuk: (1) Mengetahui bentuk-bentuk pelanggaran yang dilakukan oleh peserta didik di SD Negeri Se kecamatan Tempel. (2) Mengetahui bentukbentuk pemberian sanksi di SD Negeri Se kecamatan Tempel (3) Mengetahui teknik pelaksanaan pemberian sanksi yang diterapkan di SD Negeri se kecamatan Tempel. (4) Megetahui perubahan perilaku setelah dibrikan sanksi. Jenis penelitian adalah penelitian kualitatif deskriptif. Subjek penelitian ini adalah kepala sekolah dan dewan guru. Adapun pengumpulan data dilakukan dengan menggunakan observasi, wawancara dan dokumentasi. Sedangkan teknik menganalisis data dilakukan dengan reduksi data, penyajian data dan penarikan kesimpulan/verifikasi. Hasil penelitian ini adalah teknik pelaksanaan pemberian sanksi dibagi menjadi tiga yakni teknik penanganan ketidakdisiplinan belajar siswa yang terjadi pada saat proses belajar mengajar, teknik penanganan ketidakdisiplinan belajar siswa yang terjadi di luar kelas dan tergolong kategori ringan, serta teknik penanganan ketidakdisiplinan belajar siswa yang terjadi di luar kelas dan tergolong jenis pelanggaran berat.
\end{abstract}

Kata kunci: sanksi, ketidakdisiplinan belajar, siswa

\begin{abstract}
This study aims to: (1) Know the forms of violations committed by learners in the State Elementary School District Tempel. (2) Knowing the forms of sanction in State Elementary School of the District of Tempel (3) To know the implementation technique of sanction applied in SD Negeri in Tempel sub-district. (4) Meg knows the behavior change after the sanction has been executed. The type of research is descriptive qualitative research. The subject of this study is the principal and the teacher council. The data collection is done by using observation, interview and documentation. While the technique of analyzing data is done by data reduction, data presentation and conclusion / verification. The result of this research is technique of implementation of giving sanction divided into three that is handling technique of student learning disorder which happened at the time of learning process, handling technique of student learning disiplinlin which happened outside of class and classified as light category, and technique of handling of indiscipline of student learning that happened outside class and classified as serious violations.
\end{abstract}

Keywords: sanction, undisciplined learning, students

Info Artikel

Diterima Februari 2018, disetujui Maret 2018, diterbitkan Juni 2018

Dipublikasikan Oleh: Program Studi Bimbingan dan Konseling 


\section{PENDAHULUAN}

Pendidikan merupakan suatu pembentukan dan pengembangan kepribadian manusia secara menyeluruh, yakni pembentukan dan pengembangan potensi yang ada pada diri manusia secara menyeluruh. Oleh karena itu, dalam proses pendidikan harus menekankan pada ilmu pengetahuan (kognitif) juga diarahkan pada pengembangan kecerdasan untuk dapat belajar cepat dengan terampil dan dalam melaksanakan sesuatu (psikomotor) serta diarahkan pada pengembangan sikap mental dan kepribadian untuk terjun di masyarakat (afektif).

Berdasarkan Undang-undang RI No. 20 tahun 2003, tentang Sistem Pendidikan Nasional Pasal 1 yang berbunyi sebagai berikut :

Pendidikan nasional berfungsi mengembangkan kemampuan dan membentuk watak serta peradaban bangsa yang bermartabat dalam rangka mencerdaskan kehidupan bangsa. Bertujuan mengambangkan potensi peserta didik agar menjadi manusia yang beriman dan bertaqwa kepada Allah SWT, berakhlak mulia, sehat berilmu, cakap, kreatif, manidri dan menjadi warga Negara yang demokratis serta bertanggung jawab. (UU dan PP Nomor 20 Tahun 2003:87).

Sehubungan dengan tujuan pendidikan sebagaimana terungkap di atas yakni untuk mengembangkan potensi kognitif, sikap dan keterampilan peserta didik maka pendidik memikul tanggung jawab untuk membimbing, mengajar dan melatih murid atas dasar norma-norma yang berlaku baik norma agama, adat, hukum, ilmu dan kebiasaan-kebiasaan yang baik.

Untuk mewujudkan tujuan itu perlu ditanamkan sikap disiplin, tanggung jawab, berani mawas diri, beriman dan lain-lain. Kedisiplinan yang dilaksanakan saat ini cenderung sudah merosot dikalangan siswa karena istilah disiplin sering kali dianggap sepele, dalam arti mudah diucapkan dan dipahami tetapi mudah diabaikan dalam pelaksanaannya. Apa bila terjadi pelanggaran terhadap tata tertib, maka akan berakibat negatif bagi hasil pembelajaran itu sendiri, terutama terhadap prestasi yang diraihnya.

Dalam menghadapi anak-anak didik yang tidak mentaati tata tertib dan kewajiban serta tugas yang diberikan, maka mereka dapat diberi Sanksi. Pemberian sanksi di sekolah dibuat bukan sebagai pembalasan. Tetapi dibuat untuk memperbaiki perilaku anak-anak lain dari kesalahan yang sama. Anak-anak yang kian tidak disiplin dengan peraturan dalam ruangan kelas harus dipisahkan dari anak-anak lain, karena mereka tidak menghormati hak-hak orang banyak dari kemaslahatan mereka, dengan demikan melindungi anak-anak dan sifat jahatnya. 
Apabila pemberian sanksi sama sekali tidak diadakan niscaya perilaku siswa akan lebih tidak disiplin pada saat Kegiatan Belajar Mengajar (KBM). Kita bisa menduga-duga, ada penerapan sanksi saja siswa yang melanggar masih banyak, apalagi jika pemberian sanksi ditiadakan, maka akan lebih tidak disiplin. Jika sanksi itu diadakan menuntut konsekuensi bagi para pendidik itu sendiri. Maksudnya, pendidik harus benarbenar bisa sebagai suri tauladan bagi anak didiknya. Penerapan aturan sanksi bagi para siswa yang melanggar tetapi tidak diikuti kedisiplinan pendidik, bagaikan halilintar di waktu siang bolong, banyak yang menyepelekan.

Banyak sekolah telah menetapkan tindakan sanksi berupa fisik, namun tetap saja tidak mengalami keberhasilan dan terus terjadi pelanggaran secara berulangulang. Jika demikian, maka sekolah harus menetapkan kebijakankebijakan sanksi yang tidak hanya sekedar sanksi seperti biasa, melainkan hukuman yang justru membuat pelakunya mendapat kebaikan-kebaikan dunia dan akhirat. Diantara banyaknya sanksi yang ditetapkan adalah berupa sanksi pemberian tugas seperti membaca dan mengahafal Qur'an. Harapannya dari sanksi ini tidak saja melakukan perbaikan tetapi peningkatan amal menuju hamba yang bertakwa.

Oleh sebab itu, dengan adanya pemberian sanksi maka akan terjalinlah kedisipilinan siswa di sekolah yang diharapkan dalam tujuan pedidikan tersebut selain kratif, mandiri cakap dan berilmu dan sehat yang paling mendasar memiliki akhlak yang mulia, bertaqwa kepada Allah SWT dan bertanggung jawab. Harapan ideal tersebut dapat dicapai bila salah satu faktornya yang harus diperhatikan adalah bila siswa selalu bersikap disiplin dan memiliki rasa tanggung jawab di sekolah.

Di seluruh SD Negeri Kecamatan Tempel sudah terdapat tata tertib bagi siswa. Tata tertib siswa di seluruh SD Negeri Kecamatan Tempel antara lain adalah siswa bertingkah laku sopan, jujur dengan berlandaskan budi pekerti yang luhur. Siswa juga diwajibkan berpakaian rapi, bersih,dan sopan sesuai dengan peraturan yang telah ditentukan oleh sekolah. Tata tertib lain dalam pembelajaran salah satu poinnya adalah siswa harus sudah berada di kelas sebelum pembelajaran dimulai.

Berdasarkan hal tersebut, maka peneliti tertarik untuk melakukan penelitian terhadap permasalahan hukuman tanpa kekerasan atau pukulan, dengan judul penelitian "Pemberian Sanksi terhadap Ketidakdisiplinan Belajar Siswa Kelas V, di SD Negeri Se Kecamatan Tempel". Apadapun dari SD se Kecamatan Tempel, penulis mengambil 5 SD Negeri yang akan menjadi tempat penulis meneliti . Nama-nama SD itu adalah SD Negeri Klegung 1, SD Negeri Klegung 3, SD 
Negeri Gaten, SD Negeri Watupecah, SD Negeri Margorejo.

\section{LANDASAN TEORI}

\section{Pengertian Sanksi}

Berbicara mengenai Sanksi, maka sebaiknya membahas tentang artinya terlebih dahulu. Sanksi adalah suatu tindakan berupa hukuman yang diberikan kepada orang yang melanggar peraturan.( Topowijono dkk. 2004). Sementara itu Muh. Arifin (1994:218) mengemukakan pengertian sanksi sebagai suatu pemberian rasa nestapa pada diri anak didik akibat dari kelalaian perbuatan atau tingkahlaku yang tidak sesuai dengan tata nilai yang diberlakukan dalam lingkukangan hidupnya.

Dari pengertian-pengertian yang telah disebutkan di atas meskipun ada sedikit perbedaan tetapi pada dasarnya mempunyai maksud yang sama bahwa sanksi adalah pemberian suatu hukuman yang negatif sebagai konsekwensi dari kelakuan yang negatif pula sehingga dapat menimbulkan penderitaan dan nestapa dengan tujuan agar anak menjadi sadar terhadap perbuatannya yang salah dan berjanji tidak mengulanginya lagi.

\section{Pandangan Tokoh Pendidikan} Islam Terhadap Pemberian Sanksi

Al-Ghazali tidak sependapat dengan pemberian sanksi pada anak didik. Beliau menjelaskan bahwa pemberian sanksi harus melalui proses yaitu : jika ada seorang anak didik yang berperilaku menyimpang, maka seorang guru maupun orang tua memberikan sanksi melalui tiga tahapan, yaitu tahap pertama : apabila anak didik melakukan kesalahan, maka sebagai gurunya harus memberikan kesempatan pada anak didik untuk memperbaiki diri. Dalam hal ini, anak didik diharapkan mampu menyadari kesalahan yang diperbuatnya sehingga menjadikannya untuk tidak mengulanginya lagi. (Zainuddin. 1991:85).

Ibnu Khaldun memiliki pemikiran yang sedikit berbeda dengan para pakar pendidikan sebelumnya, sebab tidak merekomendasikan pemberian sanksi dalam pendidikan. Ibnu Khaldun tidak sepakat dengan pola "militeristik" dalam berinteraksi dengan peserta didik, sebab pola-pola itu justru akan berdampak buruk bagi anak didik berupa munculnya kelainan-kelainan psikologis dan perilaku nakal. Hal ini sebagaimana diungkapkan Ibnu Khaldun: "Pendidikan yang dalam proses pembelajarannya teramat keras dan galak terhadap anak didiknya, maka sikap geras dan galak tadi membekas dalam diri anak didik, sehingga ia terlatih hidup dalam kepura-puraan, kepalsuan dan ketidakwajaran, serta nyalinya menjadi kecil. Kebiasaan ini terus berlanjut hingga membentuk kebiasaan dan akhlak anak didik. Maka nilai kemanusiaannya mengikis dan rasa egonya sirna. Bahkan lebih jauh jiwa anak didik yang bersangkutan menjadi malas untuk 
berkembang ke arah kebaikan, melainkan justru turun ke titik nol."( Ali Abd Wahid Wafi 1960:1244).

Jika merujuk pada pendapat tersebut, maka Ibnu Khaldun sudah manawarkan konsep pendidikan yang bebas, independen tetapi tetap konsisten. Dalam hal ini anak diberi ruang yang seluas-luasnya untuk berkembang tanpa ada indoktrinasi.

\section{Dasar Pemberian Sanksi}

Pendidik muslim harus mendasarkan sanksi atau hukuman yang diberikannya pada ajaran Islam, sesuai dengan Firman Allah dan sunah Rasul-Nya. Ayat al-Qur'an yang menunjukkan perintah menghukum, terdapat pada surat An-Najm ayat 31 .

Dalam ayat tersebut dijelaskan bahwa setiap perbuatan yang melanggar atau perbuatan yang jahat pasti ada sanksi atau balasannya sesuai apa yang diperbuatnya. Dan sebaliknya jika kita mengerjakan kebaikan niscaya kita akan mendapatkan kebaikan berupa pahala (hadiah/reward). Tahapan paling awal dalam memberkan sanksi adalah dengan memberikan nasehat dengan cara dan pada waktu yang tepat. Merujuk kembali kepada ayat di atas, beberapa istri sudah cukup merasa bersalah dengan cara teguran dan nasehat ini, tetapi ada juga yang tidak.

\section{Tujuan Pemberian Sanksi}

Ibrahim Amin (2006:356 ) menyebutkan bahwa tujuan pemberian sanksi adalah diperlukan untuk mendidik, menyemaikan sifat taqwa atau pengendalian diri dalam hati manusia. Kengerian akan pemberian sanksi melatih manusia untuk menahan diri, memperkuat ketabahan dan kesabaran. Sehingga lama kelamaan sifat-sifat positif akan menjadi bagian dari wataknya.

$$
\text { M.Ngalim Purwanto (1994: }
$$

175-176) mengklasifikasikan tujuan sanksi atau hukuman berkaitan dengan pendapat orang tentang teori-teori hukuman, yaitu:

1. Teori Pembalasan Menurut teori ini, sanksi diadakan sebagai pembalasan dendam terhadap pelanggaran yang telah dilakukan seseorang.

2. Teori Perbaikan Menurut teori ini, sanksi diadakan untuk membasmi kejahatan yaitu untuk memperbaiki si pelanggar agar jangan berbuat kesalahan semacam itu lagi.

3. Teori Pelindungan Menurut teori ini, sanksi diadakan untuk melindungi masyarakat dari perbuatan-perbuatan yang tidak wajar.

4. Teori Ganti Kerugian Menurut teori ini, sanksi diadakan untuk mengganti kerugian-kerugian yang telah diderita akibat dari kejahatan atau pelanggaran itu.

5. Teori Menakut-nakuti Menurut teori ini, sanksi diadakan untuk menimbulkan perasaan takut kepada si pelanggar akan akibat perbuatannya yang melanggar itu sehingga ia akan selalu takut 
melakukan perbuatan itu dan mau meninggalkannya.

Dari uraian di atas, dapat disimpulkan bahwa tiap teori itu masih belum lengkap karena masing-masing hanya mencakup satu aspek saja. Tiap-tiap teori tadi saling membutuhkan kelengkapan dari teori yang lain.

\section{Syarat Pemberian Sanksi}

Abdullah Nasih Ulwan (1994:325-327) menyebutkan persyaratan memberikan hukuman pukulan, antara lain:

1. Pendidik tidak terburu-buru.

2. Pendidik tidak memukul ketika dalam keadaan sangat marah.

3. Menghindari anggota badan yang peka seperti kepala, muka, dada dan perut.

4. Tidak terlalu keras dan tidak menyakiti.

5. Tidak memukul anak sebelum Ia berusia 10 tahun.

6. Jika kesalahan anak adalah untuk pertama kalinya, hendaknya diberi kesempatan untuk bertobat, minta maaf dan berjanji untuk tidak mengulangi kesalahannya itu.

7. Pendidik menggunakan tangannya sendiri.

8. Jika anak sudah menginjak Usia dewasa dan dengan 10 kali pukulan tidak juga jera maka boleh Ia menambah dan mengulanginya sehingga anak menjadi baik kembali.

Hal tersebut menunjukkan bahwa dalam mendidik anak, Islam membolehkan penggunaan hukuman sebagai sarana untuk meluruskan dan menyadarkan anak dengan sesuatu yang tidak menyakitkan atas kekeliruannya. Tentu saja yang dimaksud memukul di sini adalah pukulan yang bertujuan untuk mendidik dan tidak menyakitkan.

Dari uraian di atas, penulis melihat ada beberapa hal yang harus diperhatikan dalam suatu proses hukuman, yaitu: hukuman adalah sebuah cara terakhir yang dilakukan agar sebuah tingkah laku yang diharapkan terjadi, hukuman harus diberikan oleh orang lain yang mempunyai otoritas menghukum, hukuman tidak boleh menghilangkan harkat dan martabat seseorang, hukuman harus diasosiasikan dengan kesalahan yang diperbuat, sebisa mungkin hukuman tidak diberikan berupa hukuman fisik dan hukuman yang diberikan tidak boleh melampaui kemampuan seeorang untuk menanggungnya karena tidak akan menimbulkan efek apapun, kecuali hanya memberatkannya.

\section{Tahapan Pemberian Sanksi}

Dalam pemberian sanksi ada tahapan yang harus diperhatikan oleh pendidik, mulai dari yang teringan hingga akhirnya menjadi yang terberat, yaitu:

1. Memberikan nasehat dengan cara dan pada waktu yang tepat Yaitu dengan tidak memojokkan dan mengungkit-ungkit kekeliruannya dengan nasehat yang panjang 
lebar, karena dapat membuat anak menolak terlebih dahulu apa yang akan disampaikan. Pemilihan waktupun harus dipertimbangkan sehingga anak bisa enjoy menerima masukan.

2. Hukuman pengabaian, untuk menumbuhkan perasaan tidak nyaman dan teracuhkan di hati anak.

3. Hukuman fisik, sebagai tahap akhir dengan catatan bahwa hukuman fisik (pukulan) yang diberikan tidaklah terlalu keras dan menyakitkan.( Istadi, Irawati. 2005:94-96).

\section{Pengertian Kedisiplinan}

Menurut

Soegarda

Poerbakawatja (1982:81) dalam ensiklopedia pendidikan, dijelaskan sebagai berikut :

1. Disiplin adalah proses menyerahkan atau mengabdikan kehendak kehendak langsung, dorongan-dorongan, keinginan atau kepentingan kepentingan kepada suatu cita-cita atau tujuan tertentu untuk mencapai efek yang lebih besar.

2. Pengawasan langsung terhadap tingkah laku bawahan (pelajarpelajar) dengan menggunakan sistem hukuman atau hadiah.

3. Dalam sekolah, suatu tingkat tata tertib tertentu untuk mencapai kondisi yang baik guna memenuhi fungsi pendidikan.

Menurut Al-Ghozali disiplin diartikan sebagai kesediaan untuk mematuhi peraturan yang baik, demikian itu bukan hanya patuh karena adanya tekanan dari luar, melainkan kepatuhan didasari oleh adanya kesadaran tentang nilai dan pentingnya peraturan itu.( Zainudin dkk 1991:83).

Dari definisi tersebut dapat dimengerti bahwa peserta didik memerlukan kedisiplinan untuk patuh dan taat menjalankan ketertiban yang berlaku baik perintah atau larangan dalam rangka menerima proses pendidikan guna memperoleh suatu keberhasilan dalam belajar.

\section{Penyebab Ketidakdisiplinan Belajar Siswa}

Yarliani, Ikta \& Fadli, Mukhtar (2012) menyebutkan berbagai macam ketidakdisiplinan yang terjadi dapat disebabkan oleh beberapa faktor, yaitu:

1. Faktor keluarga, yaitu: orang tua yang bercerai, orang tua sering bertengkar, sikap orang tua yang acuh/kurang perhatian, dan otoriter/over protektif.

2. Faktor ekonomi keluarga, yaitu ekonomi orang tua pas-pasan, siswa harus bekerja, dan keperluanya ikut ditanggung keluarga.

3. Faktor lingkungan, baik tempat tinggal siswa maupun lingkungan sekolah yaitu: menimbulkan keberanian, suka meniru yang lain, mau menang sendiri, dan merasa diri lebih mengetahui dan hebat dari yang lain. 


\section{Penanggulangan Ketidakdisiplinan}

Disiplin individu menjadi prasyarat terbentuknya kepribadian yang unggul dan sukses. Disiplin sekolah menjadi prasyarat terbentuknya lingkungan pendidikan yang kondusif bagi kegiatan dan proses pendidikan. Oleh karena itu, kepala sekolah, guruguru dan orang tua perlu terlibat dan bertanggung jawab membangun disiplin siswa dan disiplin sekolah. Menurut Tu'u dalam penanggulangan disiplin, beberapa hal yang perlu mendapat perhatian adalah sebagai berikut:

1. Adanya tata tertib dalam mendisiplinkan siswa, tata tertib sangat bermanfaat untuk membiasakannya dengan standar perilaku yang sama dan diterima oleh individu lain dalam ruang lingkupnya. Dengan standar yang sama ini diharapkan tidak ada diskriminasi dan rasa ketidakadilan pada individu yang ada di lingkungan tersebut. Di samping itu adanya tata tertib, para siswa tidak dapat lagi bertindak dan berbuat sesuka hatinya.

2. Konsisten dan konsekuen Masalah umum yang muncul dalam disiplin adalah tidak konsistennya penerapan disiplin. Perlu sikap konsisten dan konsekuen orang tua dan guru dalam implementasi disiplin.

3. Hukuman bertujuan untuk mendidik dan menyadarkan siswa bahwa perbuatan yang salah mempunyai akibat yang tidak baik.
Tetapi hukuman bukan satusatunya cara untuk mendisiplinkan anak atau siswa.

4. Kemitraan dengan orang tua. Pembentukan individu berdisiplin dan penanggulangan masalahmasalah disiplin tidak hanya menjadi tanggung jawab sekolah, tetapi juga tanggung jawab orang tua atau keluarga.( Tu'u, Tulus. 2004:55-56)

Sedangkan Emmer dan rekanrekan sejawatnya (2006) dan Lavin dan Nolan (2000) dalam Anita woolfolk menyarankan cara-cara sederhana untuk menanggulangi ketidakdisiplinan belajar siswa, mulai dari yang paling tidak intrusif sampai paling intrusif, yaitu:

1. Lakukan kontak mata dengan, atau mendekati ke arah si pelaku.

2. Cobakan isyarat verbal seperti "name-dropping" (sisipkan nama siswa itu kedalam ceramah yang sedang disampaikan guru).

3. Tanyakan kepada siswa, apakah mereka menyadari efek-efek negatif tindakannya.

4. Bila mereka tidak melaksanakan sebuah prosedur kelas dengan benar, ingatkan siswa tentang prosedur itu dan suruh mereka untuk mengikutinya dengan benar.

5. Dengan cara yang tenang dan tidak bermusuhan, mintalah siswa untuk menyebutkan peraturan atau prosedur yang benar.

6. Beri tahu siswa dengan cara yang jelas, asertif, dan tidak bermusuhan untuk menghentikan 
perilaku berikutnya. (Woolfolk Anita. 2009:322-323).

\section{METODE PENELITIAN}

Metode penelitian ini menggunakan metode kualitatif. Metode penelitian kualitatif adalah metode penelitian yang berlandaskan pada filsafat postpositivisme, digunakan untuk meneliti pada kondisi obyek yang alamiah(sebagai lawannya adalah eksperimen), dimana peneliti adalah sebagai instrumen kunci, teknik pengumpulan data dilakukan secara triangulasi (gabungan), analisis data bersifat induktif/kualitatif, dan hasil penelitian kualitatif lebih menekankan makna dari pada generalisasi. (Sugiyono 2011: 255-264).

Populasi dalam penelitian ini adalah siswa kelas V di SD Negeri Kecamatan Tempel. Dan Teknik sampling yang digunakan dalam penelitian ini adalah purposive sampling dan snowball sampling. Sementara dalam metode pengumpulan data dengan menggunakan metode wawancara, dokumntasi dan observasi. Metode analisis data dengan menggunakan reduksi data, penyajian data, dan verifikasi data.

HASIL PENELITIAN DAN PEMBAHASAN

Bentuk-bentuk Ketidakdisiplinan Belajar Siswa di SD Negeri Kecamatan Tempel

Setelah dilakukan observasi penelitian dan dilengkapi dengan wawancara dan data dari SD Negeri

Kecamatan Tempel ini, bahwa banyak terjadi ketidakdisiplinan atau pelanggaram terhadap norma dan aturan Agama dan perbuatan asosial lainnya. Ini sejalan dengan pendapat para ahli, salah satunya adalah Menurut Fuad Hasan: ketidakdisiplinan adalah kelakuan atau perbuatan anti sosial dan anti normative, selanjutnya menurut inpres No 6/1971 pedoman 8 tentang penanggulangan ketidakdisiplinan, ketidakdisiplinan pengertiannya adalah suatu pelanggaran sikap mental yang didasari oleh tidak adanya kesadaran dan keinsyafan untuk tidak mematuhi terhadap perintah-perintah dan larangan-larangan yang ada terhadap suatu hal karena mengerti bentuk-bentuk tentang perintah dan larangan-larangan tersebut. (Nasir Ahmad Sahilun 1999:82).

Bentuk-bentuk ketidakdisiplinan belajar siswa di SD Negeri Kecamatan Tempel di antaranya, terlambat datang ke sekolah, tidak memakai seragam atau tidak merapihkan baju, tidak mengikuti salat duha, zikir bersama dipagi hari dan tidak zuhur secara berjamaah. Bentuk ketidakdisiplinan yang lainnya terjadi di dalam kelas diantaranya adalah sering membuat kegaduhan pada saat pembelajaran berlangsung, Tidak mengikuti pembelajaran tanpa alasan, dan melakukan pencurian. Selain itu adapula ketidakdisiplinan yang dilakukan di luar batas kewajaran terhadap guru, misalnya mengunci 
kepala sekolah dalam toilet, mengajak berkelahi dengan guru, dan ketidakdisiplinan yang lain seperti membawa benda terlarang dan rokok. Juga dapat dilihat pada tabel di bawah ini:

Tabel 1

Klasifikasi Pelanggaran

\begin{tabular}{|c|l|c|c|c|}
\hline NO & PELANGGARAN & \multicolumn{3}{|c|}{ KLASIFIKASI } \\
\cline { 2 - 5 } & & Ringan & Sedang & Berat \\
\hline 1 & $\begin{array}{l}\text { Terlambat datang } \\
\text { sekolah }\end{array}$ & $\mathrm{X}$ & & \\
\hline 2 & $\begin{array}{l}\text { Tidak memakai } \\
\text { seragam atau } \\
\text { pakaian tidak rapi }\end{array}$ & $\mathrm{X}$ & & \\
\hline 3 & $\begin{array}{l}\text { Tidak mengikuti } \\
\text { sholat dhuha dan } \\
\text { sholat dhuhur } \\
\text { berjamaah }\end{array}$ & & $\mathrm{X}$ & \\
\hline 4 & $\begin{array}{l}\text { Tidak mengikuti } \\
\text { pembelajaran tanpa } \\
\text { alasan }\end{array}$ & & $\mathrm{X}$ & \\
\hline 5 & $\begin{array}{l}\text { Membuat } \\
\text { kegaduhan pada } \\
\text { saat KBM }\end{array}$ & & $\mathrm{X}$ & \\
\hline 6 & Pencurian & & & $\mathrm{X}$ \\
\hline 7 & $\begin{array}{l}\text { Bertindak di luar } \\
\text { batas kepada guru }\end{array}$ & & & $\mathrm{X}$ \\
\hline 8 & $\begin{array}{l}\text { Membawa barang } \\
\text { terlarang }\end{array}$ & & $\mathrm{X}$ \\
\hline
\end{tabular}

Bentuk-bentuk Pemberian Sanksi di SD Negeri Kecamatan Tempel

Di SD Negeri Kecamatan Tempel ini, menghendaki adanya pemberian sanksi guna untuk mendisiplinkan peserta didiknya yang kerap sekali melakukan tindakan yang kian tidak disiplin. Di antara gambaran penelitian yang diperoleh oleh peneliti antara lain diperoleh gambaran yang sesuai dengan caracara yang mendidik sesuai dengan ketentuan dalam pelaksanaan dunia pendidikan. Dalam buku Ilmu Pendidikan Teoritis dan Praktis M. Ngalim Purwanto (1994:177) ada beberapa pendapat yang membedakan sanksi mejadi dua bentuk, yaitu:

1. Hukuman Preventiv, yaitu hukuman yang dilakukan dengan maksud agar tidak atau jangan terjadi pelanggaran. Jadi, hukuman ini dilakukan sebelum pelanggaran itu dilakukan.

2. Hukuman Represif, yaitu hukuman yang dilakukan oleh karena adanya pelanggaran, oleh adanya kesalahan yang telah diperbuat. Jadi, hukuman itu dilakukan setelah terjadi pelanggaran.

Syaikh Muhammad bin Jamil Zainu membagi hukuman menjadi dua bentuk, yaitu:

1. Sanksi hukuman yang Dilarang, seperti: memukul wajah, kekerasan yang berlebihan, perkataan buruk, memukul ketika marah, menendang dengan kaki dan sangat marah.

2. Sanksi hukuman yang Mendidik dan Bermanfaat, seperti: memberikan nasehat dan pengarahan, memberikan tugas, mengerutkan muka, membentak, menghentikan kenakalannya, menyindir, mendiamkan, teguran, duduk dengan menempelkan lutut ke perut, hukuman dari ayah, menggantungkan tongkat, dan 
pukulan ringan.( Abu Hanan dan Ummu Dzakiyya. 2005:167-183)

Dari Dari uraian di atas, di SD Negeri Kecamatan Tempel, dalam memberikan sanksi lebih condong kepada pendapat Syaikh Muhammad bin Jamil Zainu, yaitu dengan menggunakan bentuk-bentuk sanksi yang bersifat mendidik dan bermafaat, seperti : pemberian nasihat dan pengarahan serta pemberian tugas tambahan. Sebagaimana yang telah diungkapkan oleh kepala sekolah SD Negeri Gaten:

"di Kecamatan Tempel ini, telah dibentuk Kelompok Kerja Kepala Sekolah (K3S). Dan kami selalu ada pertemuan dan pernah menyinggung mengenai pemberian sanksi bagi para peserta didik yang kian tidak disiplin. Tentu sanksi ini sanksi yang betul-betul dapat bermanfaat bagi peserta didik kami. Karena tidak jarang ada guru yang meghukum siswa dengan cubitan atau pukulan yang terjadi malah guru itu dipejarakan karena termasuk salah satu tindakan penganiayaan. Dan dari sinilah K3S menetapkan bentuk-bentuk pemberian sanksi yang pertama adalah berupa teguran dan kemudian berupa pemberian tugas-tugas tambahan dan surat perjanjian. Dan hukuman fisik akan diberikan hanya saja kalau kondisinya sudah dalam keadaan darurat. Jika dengan tindakan tersebut tidak ada perubahan juga, maka kami akan mengadakan pemanggilan orang tua".( Hasil Wawancara dengan ibu Siti Purwanti, S.Pd.I. Kepala Sekolah SD Negeri Gaten Tempel 21 April 2017)

\section{Teknik Pelaksanaan Pemberian Sanksi dalam Ketidakdisiplinan Belajar Siswa di SD Negeri Kecamatan Tempel}

Sanksi adalah bagian dari alat pendidikan yang bersifal soft ware. Pemberian sanksi di SD Negeri Kecamatan Tempel ini dilakukan dengan tujuan perbaikan sesuai dengan teori perbaikan yang dikemukakan oleh M. Ngalim Purwanto (1995:186) bahwa menurut teori ini, Menurut teori ini, hukuman diadakan untuk membasmi kejahatan. Jadi, maksud hukuman itu ialah untuk memperbaiki si pelanggar agar jangan berbuat kesalahan semacam itu lagi. Teori ini lebih bersifat pedagogies karena bermaksud memperbaiki si pelanggar, baik lahiriah maupun batiniahnya.

Adapun teknik pelaksanaan pemberian sanksi dalam ketidakdisiplinan belajar siswa di SD Negeri Se Kecamatan Tempel adalah sebagai berikut:

1. Ketiddakdisiplinan saat $\mathrm{KBM}$ (kegiatan belajar mengajar) terdiri dari langkah-langkah sebagai berikut:

a. Pemberian nasihat oleh guru

b. Diintrogasi sebab melakukan pelanggran

c. Guru kelas menyerahkan kepada kepala sekolah 
d. Kepala sekolah memberikan sanksi sesuai dengan jenis pelanggarannya seperti memberi tugas membaca atau meulis.

e. Jika dalam mengerjakan tugas tersebut siswa tidak mampu menyelesaikan dengan waktu yang tela ditentukan, maka guru atau kepala sekolah akan memberikan sanksi berupa tindakan fisik seperti puss up, scoot jump,atau hukuman fisik yang lainnya.

2. Pelanggaran yang terjadi di luar kelas dan masuk kategori ringan.

Pelanggaran jenis ini sama saja secara teknis pelaksanaannya dengan penjelasan pertama (poin satu), hanya saja yang membedakan adalah penanganannya langsung diserahkan kepada kepala sekolah, tidak melalui guru di kelas karena pelanggrannya terjadi di luar kelas, seperti terlambat, tidak salat zuhur dll.

3. Ketidak disiplinan di luar jam pelajaran dan yang terjadi berada pada jenis pelanggaran berat.

Jenis pelanggran ini akan melalui tahapan sebagai berikut:

a. Ditangani oleh kepala sekolah

b. Diberi nasihat

c. Diintrogasi penyebabnya

d. Dihukum dengan membaca dan menulis sebagai soft terapi.

e. Kerja sama kepala sekolah dengan guru f. Diberi sanksi oleh pihak sekolah

g. Jika tidak berubah dengan sanksi yang diberikan dengan pihak sekolah maka langkah terakhir adalah pemanggilan orang tua oleh pihak sekolah.

h. Jika tetap tidak mengindahkan juga maka sekolah akan menskorsing atau mengeluarkan siswa tersebut dari sekolah.

4. Perubahan Prilaku Siswa setelah Mendapatkan Sanksi

Setelah dilakukan penelitian berdasarkan survey dan wawancara serta data yang ada, dan dari bentuk-bentuk ketidakdisiplinan di atas,ternyata siswa merasa jera terhadap sanksi yang diberikannya. Alasannya sangat beragam, di mulai dari yang datang terlambat hingga yang membawa barang terlarang seperti membawa rokok atau benda tajam. Sebagaimana hasil survey dan wanwancara di bawah ini:

a. Terlambat datang sekolah

$$
\text { Seperti }
$$
yang diungkapkan oleh Alfat:

"dulu saya memang sering terlambat, karena jarak rumah saya yang jauh. tapi setelah saya diberi sanksi untuk menulis buku sebanyak 2 bab, saya jadi berusaha datang lebih awal sehingga sekarang ini saya hampir tidak pernah terlambat lagi'( Hasil Wawancara dengan Alfat 
siswa kelas V SD Negeri Klegung 1 Tempel 12 April 2017)

Selain Alfat juga diungkapkan oleh Ardan:

"orangtua saya super sibuk kalau pagi, jadi kalau mengantar saya selalu agak siang jadinya saya terlambat terus, tapi setelah orangtua tau kalau saya selalu diberi sanksi jika datang terlambat, sekarang kalau mengantar selalu pagipagi sekali, pekerjaan dinomor duakan"( Hasil Wawancara dengan Ardan siswa kelas V SD Negeri Klegung 3 Tempel 24 April 2017)

b. Tidak seragam atau pakaian tidak rapi

Hasil wawancara dengan Raihan:

“ dulu saya sering sekali tidak memakai seragam pada hari yang ditentukan, akhirnya saya dipanggil oleh kepala sekolah diceramahai kemudian disuruh membaca buku PAI 1 bab di dalam kantor. Saat itulah saya tidak berani lagi menggunakan pakaian yang bukan harinya"( Hasil Wawancara dengan Raihan siswa kelas V SD N Gaten Tempel 16 Desember 2017)

c. Memuat kegaduhan

Hasil wawancara dengan Sadat:

"dulu saya memang sering membuat onar pada saat belajar bahkan sering mengganggu teman-teman, akhirnya saya disuruh ke kantor menghadap kepala sekolah untuk diberi peringatan setelah itu saya diambilkan buku PPKN kemudia disuruh membaca sebanyak 4 bab, ternyata capek juga akhhirnya saya gak berani lagi buat onar mengganggu teman-teman".( Hasil Wawancara dengan Sadat siswa kelas V SD Negeri Margorejo Tempel 14 Juni 2017).

Hasil atau evaluasi pelaksanaan pemberian sanksi di sekolah dapat ditunjukan pada data yang ada dan pada perilaku nilai-nilai kepedidikan. Data menunjukkan bahwa sanksi ini telah memberikan perubahan pada perilaku siswa yang kerap sekali melakukan tindakan tidak disiplin.

\section{SIMPULAN}

Berdasarkan hasil penelitian dan pembahasan maka dapat disimpulkan::

1. Bentuk-bentuk ketidakdisiplinan belajar siswa di SD Negeri Se Kecamatan Tempel yang terjadi setelah dilakukan penelitian adalah sebagai berikut:

a. Terlambat datang ke sekolah

b. Tidak memakai seragam atau tidak merapihkan baju

c. Tidak mengikuti shalat duha, zikir pagi hari dan shalat duhur berjamaah

d. Kenakalan dalam kelas 
e. Membuat kegaduhan

f. Tidak mengikuti pembelajaran tanpa alas an

g. Pencurian

h. Bertindak di luar batas kepada guru

i. Membawa barang yang terlarang

j. Terlibat perkelahian dalam lingkungan sekolah

2. Bentuk-bentuk pemberian sanksi yang diterapkan di SD Negeri Kecamatan Tempel adalah bentuk pemberian sanksi yang mendidik dan bermanfaat. sanksi dalam bentuk mendidik dan bermanfaat seperti berupa teguran, pemberian tugas lalu dibuatlah surat perjanjian dan kemudian barulah pemanggilan orang tua.

3. Teknik pelaksanaan pemberian sanksi dalam ketidakdisiplinan belajar siswa di SD Negeri Se Kecamatan Tempel di mulai dari :

a. Ketiddakdisiplinan saat KBM (kegiatan belajar mengajar) terdiri dari langkah-langkah sebagai berikut:

1) Pemberian nasihat oleh guru

2) Diintrogasi sebab melakukan pelanggran

3) Guru kelas menyerahkan kepada kepala sekolah

4) Kepala sekolah memberikan sanksi sesuai dengan jenis pelanggarannya seperti memberi tugas membaca atau meulis.
5) Jika dalam mengerjakan tugas tersebut siswa tidak mampu menyelesaikan dengan waktu yang tela ditentukan, maka guru atau kepala sekolah akan memberikan sanksi berupa tindakan fisik seperti puss up, scoot jump,atau hukuman fisik yang lainnya.

4. Pelanggaran yang terjadi di luar kelas dan masuk kategori ringan.

Pelanggaran jenis ini sama saja secara teknis pelaksanaannya dengan penjelasan pertama (poin satu), hanya saja yang membedakan adalah penanganannya langsung diserahkan kepada kepala sekolah, tidak melalui guru di kelas karena pelanggrannya terjadi di luar kelas, seperti terlambat, tidak salat zuhur dll.

5. Ketidak disiplinan di luar jam pelajaran dan yang terjadi berada pada jenis pelanggaran berat.

Jenis pelanggran ini akan melalui tahapan sebagai berikut:

a. Ditangani oleh kepala sekolah

b. Diberi nasihat

c. Diintrogasi penyebabnya

d. Dihukum dengan membaca dan menulis sebagai soft terapi.

e. Kerja sama kepala sekolah dengan guru

f. Diberi sanksi oleh pihak sekolah. 
g. Jika tidak berubah dengan sanksi yang diberikan dengan pihak sekolah maka langkah terakhir adalah pemanggilan orang tua oleh pihak sekolah.

h. Jika tetap tidak mengindahkan juga maka sekolah akan menskorsing atau mengeluarkan siswa tersebut dari sekolah.

6. Perubahan perilaku siswa kelas V di SD Negeri Kecamatan Tempel setelah diterapkan pemberian sanksi, terdapat siswa yang menyatakan telah menunjukkan perubahan perilaku yang lebih baik dan disiplin.

\section{DAFTAR PUSTAKA}

Amini, Ibrahim. 2006. Agar Tak Salah Mendidik Anak. Jakarta: AlHuda.

H. M. Arifin. 1994. Ilmu Pendidikan Islam. Jakarta: Bumi Putra.

Nasir Ahmad Sahilun. 1999. Peranan Pendidikan Agama Terhadap Pemecahan Problema Remaja. Jakarta: Kalam Mulia.

Nawawi, Imam Kasyifatu As-Saja. 1985.(Syarah Safinat An-Naja). Toha Putra. Semarang.

Purwanto, M. Ngalim. 1994. Psikologi Pendidikan. Remaja Rosdakarya. Bandung.

Poerbakawatja, Soegarda. 1982. Ensiklopedi Pendidikan. Gunung Agung. Jakarta.
Sugiyono, 2011. Metode penelitian kuantitatif, kualitatifdan R\&D. Bandung: Al-Fabeta.

Tu'u, Tulus. 2004. Peran Disiplin Pada Perilaku dan Prestasi Siswa. Garsindo Jakarta.

Topowijono dkk, Pengaruh Sanksi Administrasi Sosialisasi Perpajakan dan Kesadaran Wajib Pajak Terhadap Kepatuhan Penyampaian SPT Tahunan Wajib Pajak Orang Pribadi. Jurnal e-Perpajakan, No. 1 volume 1 tahun 2014.

Ulwan, Abdullah Nasih. 1994. Pendidikan Anak dalam Islam. Terj. Jamaludin Miri. Pustaka Amani. Jakarta.

Woolfolk Anita. 2009. Education Psychology: Active Learning Edituon. Terjemahan Helly Prajitno Soetjipto dan Sri Mulyantini Soetjipto. Pustakan Pelajar. Cet. Pertama. Edisi ke10 Bagian kedua. Yogyakarta.

Yarliani, Ikta \& Fadli, Mukhtar. Penyebab Perilaku Tidak Disiplin pada Siswa .Jurnal Ta'lim Muta'allim, Vol. II Nomor 4 Tahun 2012.

Zainudin dkk 1991. Seluk -beluk Pendidikan al-Ghozali. Bumi Aksara. Jakarta.

Zainu, Syaikh Muhammad bin Jamil. 2005. Seruan Kepada Pendidik dan Orangtua. Terj. Abu Hanan dan Ummu Dzakiyya. Pustaka Hidayah. Solo. 